\title{
EFFECT OF Euxestophaga argentinensis (HYMENOPTERA, FIGITIDAE) ON CORN-SILK FLY LARVAE Euxesta sp. IN TWO SWEET CORN PLANTING DATES.
}

\section{EFECTO DE Euxestophaga argentinensis (HYMENOPTERA, FIGITIDAE) SOBRE LARVAS DE LA MOSCA DE LA MAZORCA Euxesta sp. EN DOS FECHAS DE SIEMBRA DE MAÍZ DULCE.}

\author{
Isabel Bertolaccini ${ }^{1 *}$, María Cecilia Curis ${ }^{1}$, Alejandra Lutz ${ }^{1}$, Juan Carlos Favaro ${ }^{1}$, Luciana Bollati ${ }^{2}$, \\ and Fabiana Gallardo ${ }^{3}$
}

\begin{abstract}
${ }^{1}$ Facultad de Ciencias Agrarias, Universidad Nacional del Litoral, Departamento de Producción Vegetal, Kreder 2805, (3080) Esperanza, Santa Fe, Argentina. E-mail: isabelb@fca.unl.edu.ar; mcuris@fca.unl. edu.ar; alutz@fca.unl.edu.ar; jcfavaro@fca.unl.edu.ar

${ }^{2}$ Facultad de Ciencias Agrarias, Universidad Nacional del Litoral, Kreder 2805, Esperanza, Santa Fe, Argentina. E-mail: lubollati@gmail.com

${ }^{3}$ Universidad Nacional de La Plata, División Entomología, Facultad de Ciencias Naturales y Museo, Paseo del Bosque s/n, B1900FWA, La Plata, Argentina. E-mail: gallardo@fcnym.unlp.edu.ar

${ }^{*}$ Correspondence author E-mail: isabelb@fca.unl.edu.ar.
\end{abstract}

\begin{abstract}
Euxesta sp. (corn-silk fly) is a highly polyphagous insect genus that affects horticultural crops, fruit trees, and industrial crops. It causes huge economic losses in sweet corn (maize). Damage is caused by larvae feeding on corn silk, kernels and the remainder of the cob. Chemical treatments applied to maize crops are often not effective; therefore, efforts to control the fly must focus on finding alternative methods, such as biological control. The aim of this work was to determine the effects of Euxestophaga argentinensis (Hymenoptera, Figitidae) parasitism on corn-silk fly larvae, in two different planting dates: late winter and late summer. Samples were taken during spring and autumn in a commercial $B t$ sweet corn for two consecutive years. A total of 20 ears of corn per sample were collected at random and were placed in plastic trays, stored at $22 \pm 2{ }^{\circ} \mathrm{C}$ and $70 \pm 5 \% \mathrm{RH}$ and exposed to a 14:10 h photoperiod. Euxesta eluta and Euxesta mazorca pupae were separated, placed in separate plastic vials and periodically checked for emergence of adult flies and parasitoids. $E$. eluta has greater potential to damage sweet corn crops than E. mazorca. Parasitism was higher in late winter than in late summer, while only E. eluta was parasitized.
\end{abstract}

Key words: Euxesta sp., maize, parasitoid, biological control.

\section{RESUMEN}

Euxesta spp. (mosca de la mazorca) es un género de insectos altamente polífagos que afectan los cultivos hortícolas, árboles frutales y cultivos industriales. En el maíz dulce causa altas pérdidas económicas. El daño es causado por la alimentación de la larva sobre los estigmas, granos y restos de la mazorca. Los tratamientos químicos aplicados a los cultivos del maíz frecuentemente no son efectivos, por lo tanto los esfuerzos en el control deben focalizarse en métodos alternativos, como el control biológico. El objetivo de este estudio fue determinar el efecto del parasitoide Euxestophaga argentinensis (Hymenoptera, Figitidae) sobre las larvas de la mosca, en dos épocas de siembra: fin de 
invierno y fin de verano, en lotes comerciales de maíz dulce $B t$, en dos años consecutivos. Un total de 20 mazorcas de maíz por muestreo fueron recolectados al azar y se colocaron en bolsas plásticas herméticas y fueron mantenidos en laboratorio a $22 \pm 2^{\circ} \mathrm{C}, 70 \pm 5 \% \mathrm{RH}$ y a 14:10 h de luz:oscuridad. Las pupas de E. eluta y E. mazorca fueron colocadas individualmente en tubos plásticos y revisados periódicamente hasta la emergencia del adulto de la mosca o del parasitoide. E. eluta tiene mayor potencial de daño que E. mazorca en los cultivos de maíz dulce. El parasitismo fue mayor en los cultivos sembrados en verano que en los de invierno tardío y solo E. eluta fue parasitada.

Palabras clave: mosca de la mazorca, maíz, parasitoide, control biológico.

\section{INTRODUCTION}

Sweet and super-sweet corn hybrids with the Bt (Bacillus thuringiensis) gene can reduce the use of insecticides for the control of lepidopteran pests. Unfortunately, the appearance of Bt sweet corn has caused the emergence of new primary pests, which were previously considered as secondary. One of these is the corn-silk fly (Euxesta eluta Loew), which previously was adequately controlled indirectly by insecticide applications used to control lepidopteran pests. The Euxesta genus belongs to the family Ulidiidae, which is represented by 36 species widely distributed in the Americas. These flies are highly polyphagous, affecting many horticultural crops, fruit trees, and industrial crops, including sweet corn (Viana et al., 2002), in which they produce huge economic losses (Seal et al., 1996; Nuessly y Capinera, 2006). In the USA, extensive damage can be caused by larvae feeding on silk, kernels and the cob itself (Seal et al., 1996; Nuessly and Capinera, 2010). Larvae are especially voracious during spring and summer, and they also cause indirect losses by encouraging the incursion of other pests and diseases where plant tissues are damaged and therefore vulnerable to attack.

E. eluta Loew and Euxesta mazorca Steyskal can be found in the peri-urban horticultural area of Santa $\mathrm{Fe}$, Argentina (Bertolaccini et al., 2010). However, their incidence and economic importance in commercial maize crops in Argentina has not been studied in depth yet. Furthermore, their impacts are probably underestimated. In fact, chemical treatments are often not effective in maize because the dense canopy does not allow adequate spray coverage near the end of the crop cycle. In addition, spray only affects adult flies; eggs and larvae are protected inside corn ears, while pupae are not affected because they are covered by soil (Nuessly y Capinera, 2010). Therefore, efforts to combat the corn-silk fly must focus on alternative methods, such as biological control, for the management of this pest as part of an integrated pest management (IPM) program.

Gallardo et al. (2017) first described an E. eluta larval parasitoid, Euxestophaga argentinensis
(Hymenoptera, Figitidae) found in the horticultural area of Santa Fe Province, where concentrated corn-silk fly attacks often damage cobs to the point of severely reducing the commercial value of the crop.

The aim of this study was to determine the effects of natural parasitism by E. argentinensis on corn-silk fly populations in Bt sweet corn in two different planting dates.

\section{MATERIALS AND METHODS}

\section{Study area}

The study was conducted in a commercial field, located at Angel Gallardo (31 $30^{\circ}$ S, 60 $43^{\prime}$ $\mathrm{W})$, corresponding to the horticulture area near Santa Fe city (Santa Fe province, Argentina). The climate was classified as Cfa: temperate humid mesothermal, according to Köppen (1948) and the soil of the experimental plot was classified as siltyloam Typic Argialbol Ascochinga Series (14\% clay; $67.6 \%$ silt; $18.4 \%$ sand) (INTA, 1991). Crops were seeded at $70 \mathrm{~cm}$ between rows under conventional soil tillage.

\section{Environmental conditions during the crop cycle}

The weather data: temperature, total rainfall, average $\mathrm{RH}$ and average wind speed were collected from readings taken at the nearby Sauce Viejo Aerodrome by TuTiempo.net (2017) during the spring and autumn maize cropping cycles (n $=4$ cycles). Data of environmental conditions data are shown in Table 1.

\section{Insect sampling}

Insect sampling was carried out in commercial crops of Bt supersweet corn, hybrid GSS0974 (Syngenta Seeds, LLC, Minnetonka, Minnesota, USA). Plots of 0.5 ha were sampled for each test; planting density was 50,000 plants $\mathrm{ha}^{-1}$. In the Ángel Gallardo region, sweet corn is harvested twice a year, in spring and autumn. Therefore, an equal number of plots (two) were selected from four consecutive sowing dates: two in late winter (August 8, 2015 and August 16, 2016), and two in late summer (February 5, 2016 and January 25 , 2017).The aim was to describe the parasitism of host E. eluta and E. mazorca corn-silk flies by 
Table 1. Environmental conditions during the maize crop cycle: average, maximum and minimum temperature $\left({ }^{\circ} \mathrm{C}\right)$, total rainfall $(\mathrm{mm})$, average $\mathrm{RH}(\%)$ and average wind speed $\left(\mathrm{km} \mathrm{h}^{-1}\right)$.

Tabla 1. Condiciones climáticas durante el ciclo del cultivo del maíz: temperatura media, máxima y mínima $\left({ }^{\circ} \mathrm{C}\right)$, lluvias totales $(\mathrm{mm})$, HR media $(\%)$ y velocidad media del viento $\left(\mathrm{km} \mathrm{h}^{-1}\right)$.

\begin{tabular}{llrrrrrr}
\hline Planting dates & $\begin{array}{l}\text { Months when } \\
\text { data were } \\
\text { recorded }\end{array}$ & $\begin{array}{c}\text { Average } \\
\text { temp. }\left({ }^{\circ} \mathrm{C}\right)\end{array}$ & $\begin{array}{c}\text { Maximum } \\
\text { temp. }\left({ }^{\circ} \mathrm{C}\right)\end{array}$ & $\begin{array}{c}\text { Minimum } \\
\text { temp. }\left({ }^{\circ} \mathrm{C}\right)\end{array}$ & $\begin{array}{c}\text { Total rainfall } \\
(\mathbf{m m})\end{array}$ & $\begin{array}{c}\text { Average RH } \\
(\mathbf{\%})\end{array}$ & $\begin{array}{c}\text { Average wind } \\
\text { speed }\left(\mathbf{k m ~ h}^{-1}\right)\end{array}$ \\
\hline Aug. 8, 2015 & August & 16.5 & 22.3 & 12.0 & 116.1 & 75.4 & 14.3 \\
& September & 16.0 & 23.1 & 10.3 & 11.4 & 63.5 & 13.0 \\
& October & 17.9 & 24.6 & 13.0 & 99.3 & 65.5 & 14.5 \\
& November & 21.5 & 27.5 & 16.4 & 140.9 & 66.2 & 12.9 \\
\hline Feb. 5, 2016 & February & 26.5 & 32.1 & 21.4 & 266.4 & 71.7 & 10.4 \\
& March & 21.7 & 27.1 & 16.6 & 67.3 & 73.5 & 10.4 \\
& April & 19.1 & 23.5 & 16.0 & 356.8 & 82.8 & 13.8 \\
\hline Aug. 16, 2016 & August & 14.5 & 21.8 & 8.2 & 2.8 & 67.7 & 11.7 \\
& September & 15.6 & 23.6 & 9.4 & 24.6 & 62.2 & 14.7 \\
& October & 18.9 & 25.0 & 14.2 & 416.3 & 70.5 & 13.6 \\
& November & 21.5 & 28.7 & 15.6 & 243.8 & 63.8 & 12.2 \\
\hline \multirow{5}{*}{ Jan. 25, 2017 } & December & 26.9 & 31.5 & 17.9 & 26.4 & 64.4 & 11.1 \\
& January & 24.5 & 31.5 & 18.6 & 186.7 & 69.4 & 12.2 \\
& February & 24.7 & 30.6 & 20.2 & 145.8 & 75.4 & 9.8 \\
& March & 22.7 & 28.7 & 17.7 & 73.4 & 69.9 & 9.8 \\
\hline
\end{tabular}

Source: TuTiempo.net (2017) (Sauce Viejo Aerodrome).

hymenopteran E. argentinensis on a seasonal basis. Samples were taken by randomly selecting and removing 20 ears of corn per plot. The ears of corn were analyzed at the Agricultural-Zoological Laboratory, Universidad Nacional del Litoral, Santa Fe, Argentina.

\section{Larvae rearing}

In the laboratory, infested corn ears were placed in ten plastic trays $(30 \mathrm{~cm}$ wide, 40 long, $12 \mathrm{~cm}$ high). Moisture was provided by adding sterile humid sand at the bottom of each tray and the layer of sand was covered with plastic film. The trays were stored at $22 \pm 2{ }^{\circ} \mathrm{C}, 70 \pm 5 \%$ relative humidity $(\mathrm{RH})$ and photoperiod was $14: 10$ h (light:dark). Pupae were removed from the corn ears or the sand every 2 days. Each pupa was placed individually in $1.5 \mathrm{~mm}$ Eppendorf ${ }^{\circledR}$ vials (SigmaAldrich, St Louis, Missouri, USA), with a damp paper inside to preserve moisture. The pupae were observed periodically to check for the emergence of adult flies or parasitoids. The pupae that did not emerge, possibly due to methodological fails, were dissected under a stereomicroscope (Olympus SZ40, Olympus Corporation, Tokyo, Japan) set at 40x magnification to determine the presence of either a fly, the parasitoid or a disease. Individuals in non-emergent pupae that could be clearly identified either as fly or wasp, were included in insect counts, while pupae with interiors liquefied by disease were recorded as sick, and excluded from the percentage parasitism. Adult parasitoids were identified in the Faculty of Natural Sciences and Museum, La Plata, Argentina.

\section{Data analysis}

The number of adult corn silk-flies, sick (liquefied) pupae, and adult parasitoids were recorded. Percentage parasitism was determined according to total pupae per planting (four plantings) and per season (two seasons, spring and autumn).

\section{RESULTS AND DISCUSSION}

The total number of pupae obtained in the laboratory differed between spring and autumn harvest. The maximum number of pupae $(n=992)$ were collected from the first late winter sowing (spring harvest), and the minimum number of pupae ( $n=133$ pupae) were collected from the late autumn planting on Jan. 25, 2017 (autumn harvest). Two species of corn-silk fly species were present, E. eluta and E. mazorca; the former was found in all four crops of sweet corn, but E. mazorca was only present in small numbers $(n=8$ emergent adults) in the corn crop planted on February 5, 2016 (Table 2).

\section{Species dominance}

These results agree with the results of Cruz et al. (2011), who found that in Brazil, E. eluta 
Table 2. Number of Euxesta sp. corn-silk fly and Euxestophaga. argentinensis, diseased pupae, total pupae count, and parasitism rate (\%) in two sweet corn planting dates.

Tabla 2. Número de adultos de mosca de la espiga y de E. argentinensis, pupas enfermas, total de pupas y parasitismo (\%), en dos épocas de siembra de maíz dulce.

\begin{tabular}{lcccccc}
\hline Planting date & $\begin{array}{c}\text { E. mazorca } \\
\text { adults }\end{array}$ & $\begin{array}{c}\text { E. eluta } \\
\text { adults }\end{array}$ & E. argentinensis & $\begin{array}{c}\text { Diseased } \\
\text { pupae }\end{array}$ & $\begin{array}{c}\text { Total pupae } \\
\text { count }\end{array}$ & $\begin{array}{c}\text { Parasitism } \\
\text { (\%) }\end{array}$ \\
\hline Aug. 8, 2015 & 0 & 788 & 117 & 87 & 992 & 12.9 \\
Jan. 5, 2016 & 8 & 311 & 1 & 25 & 345 & 0.3 \\
Aug. 16, 2016 & 0 & 251 & 30 & 3 & 284 & 10.7 \\
Jan. 25, 2017 & 0 & 105 & 18 & 10 & 133 & 14.6 \\
\hline
\end{tabular}

Note: Diseased pupae were excluded from percentage parasitism calculations.

is the predominant species. The dominance of E. eluta could indicate better adaptation to corn than E. mazorca (Huepe et al., 1986). In addition, both species of fly shows different responses to environmental factors, which is further complicated by the fact that corn kernels water content influences the reproductive dynamics of these species (Souto et al., 2011). In fact, species of Euxesta are influenced by both temperature and humidity. They may occupy different ecological niches at certain times, but they may also coexist during certain seasons of the year (Frías, 1981; Cruz et al., 2011).

\section{Environmental conditions}

Adult flies exhibited decreased activity when the wind speed was lower than $24 \mathrm{~km} \mathrm{~h}^{-1}$, which is in agreement with the results of Seal et al. (1996). Average wind speed remained below $24 \mathrm{~km} \mathrm{~h}^{-1}$ on all the dates, so others environmental factors rather than wind speed (temperature, $\mathrm{RH}$, rainfall) could have influenced the number of pupae found in the corn (Table 1).

Frías (1978) found that E. eluta is adapted to colder temperatures in Chile, reaching its greatest abundance in the months of March and April, which is the time maize is harvested in that country. In the present study, there were no significant differences in mean, maximum and minimum temperature across the four sampling dates (Table 1); however, the number of pupae obtained was variable, ranging from 992 (firth date of planting) to 133 (last sowing) (Table 2).

E. eluta larvae develop mainly in cobs at the advanced stage of development (Curis et al., 2015). Temperature could probably explain the variation in corn-silk fly counts between the spring and autumn harvests since corn-silk attacks occur at lower temperatures because the predominant species, E. eluta, prefers these conditions. This factor could affect emergent fly numbers, but it does not explain interannual variation.

Rainfall could have a direct effect on adult flies because attacks on corn occur in the last few months before harvest. In addition, rainfall could also directly affect the pupae in the soil; if precipitation is heavy, water may saturate the soil and negatively impact pupae health. MacRae and Armstrong (2000) found that a fly from the same family, Tetanops myopaeformis (Diptera, Ulidiidae), had significantly greater pupal mortality in soils with more than $45 \%$ soil moisture by weight, and that soils ranging from $10-30 \%$ soil moisture had no significant effect on pupal development or on the number of adults emerging.

The results obtained herein showed that there was a negative correlation between rainfall and corn-silk fly numbers. Fly number increased in crops that grew under conditions of lower precipitation, and rainfall could account for this situation.

\section{Parasitism}

A number of 117 emerging adults of the hymenopteran E. argentinensis were found in the first crop sampled, which indirectly represents a $14.8 \%$ parasitism rate. Average parasitism rate $(11.8 \%)$ was greater in the spring harvest, ranging from 10.7 to $12.9 \%$. In contrast, parasitism was $0.3 \%$ in the first autumn crop, while the larvae collected in the second autumn crop reached a significantly higher rate (14.6\%) (Table 2 ).

\section{The biocontrol option}

In recent years, the increased use of $B t$ sweet corn has allowed growers to reduce insecticide applications targeting Lepidopteran pests, but attacks of corn-silk fly have increased. Chemical insecticides are currently the only effective technique for the control of corn-silk fly in sweet corn (Kalsi et al., 2014). Currently, available insecticides kill adult flies but have no effects on the other life stages of a fly. This occurs because immature flies (eggs and larvae) are protected inside corn ears, and as pupae, the flies are buried in the soil, well out of reach of insecticide 
penetration (Nuessly y Capinera, 2010). Therefore, biological control agents may be helpful, but to-date, there is no field-ready and quantitative information available on the biocontrol of Ulidiidae flies in Argentina (Kalsi et al., 2014).

Recently, new parasitoids of corn-silk fly have been described in other countries. In Mexico, Spalangia spp. (Hymenoptera, Pteromalidae) has been reported as attacking corn-silk fly species (Camacho-Báez et al., 2012). Pachycrepoideus vindemmiae (Hymenoptera, Pteromalidae) has been observed parasitizing Euxesta spp. pupae in the state of Florida, USA (Owens et al., 2015). In Argentina, the genus Euxestophaga and the species $E$. argentinensis have been observed parasitizing corn-silk fly (E. eluta) in sweet corn fields in Santa Fe (Gallardo et al., 2017), observations corroborated by quantitative results in the current study.

Newly recorded parasitoids offer possibilities for biocontrol against flies attacking corn crops during the growing season, and high parasitism rates may impact the next generations of flies, thus decreasing crop damage (Camacho-Báez et al., 2012). The current study is a contribution to knowledge about the larval parasitoid of Euxesta spp., recently described in Argentina. It also represents an important initial step in determining the efficacy of E. argentinensis as a viable biocontrol option.

However, further studies are required to determine other possible hosts of E. argentinensis, their biological life cycles, and others parasitoids of the corn-silk fly present in Argentina. In addition, it is also necessary to search for a parasitoid specific to E. mazorca. Even though it was present in low numbers in the corn ears examined in the current study, its status as a pest may evolve over time, especially if E. eluta infestations are successfully curbed, thus opening a niche for $E$. mazorca. Finally, it is essential to determine the long-term efficacy of parasitoids in controlling corn-silk and other Ulidiidae crop pests. As this species was recently described, future studies on biology and laboratory breeding are required to achieve field releases of the parasitoid for the biological control of corn-silk fly.

\section{CONCLUSIONS}

Euxesta eluta was the dominant species of corn silk-fly and was the only parasitized by Euxestophaga argentinensis. Parasitism was independent of sweet corn planting dates: it was higher in corn planted in late winter, in the first year $(12.9 \%)$, while larvae collected in the second autumn crop (late summer planting date) reached a significantly higher rate of parasitism (14.6\%).

\section{ACKNOWLEDGMENTS}

Financial support for this study was provided by the Universidad Nacional del Litoral, Argentina, Curso de Acción para la Investigación y Desarrollo (CAI+D) Program (project grant 501 20110100009 LI). Our deepest appreciation goes to the Universidad Nacional de La Plata and Comisión de Investigaciones Científicas de la Provincia de Buenos Aires (CICPBA), Argentina, for their continued support.

\section{DISCLOSURE}

The authors report no conflicts of interest in this work.

\section{LITERATURE CITED}

Bertolaccini I., C. Bouzo, N. Larsen, y J.C. Favaro. 2010. Species of the genus Euxesta (Diptera: Ulidiidae = Otitidae), pests of Bt sweet corn in Santa Fe province, Argentina. Rev. Soc. Entomol. Argent. 69:123-126.

Camacho-Báez, J.R., C. García-Gutiérrez, M. Mundo-Ocampo, A.D. Armenta-Bojorquez, E., Nava-Pérez, J.I. Valenzuela-Hernández, et al. 2012. Natural enemies of corn stigma flies: Euxesta stigmatias (Loew), Chaetopsis massyla (Walker) and Eumecosommyia nubila (Wiedemann) in Guasave Sinaloa, Mexico. Ra Ximhai 8(3):71-77.

Cruz, I., R. Braga da Silva, M. Corrêa Figueiredo, A.M. Penteado-Dias, M.C. Laboissiérè Del Sarto, and G.S. Nuessly. 2011. Survey of ear flies (Diptera, Ulidiidae) in maize (Zea mays L.) and a new record of Euxesta mazorca Steyskal in Brazil. Rev. Bras. Entomol. 55(1):102-108.

Curis, M., M. Re, J.C. Favaro, D. Sánchez e, I. Bertolaccini. 2015. Euxesta spp. Nueva plaga en Zea mayz L. variedad rugosa: asociación con ataques de Heliothis zea en siembras de primavera y verano. Trop. Subtrop. Agroecosyst. 18:251-257.

Frías, D.L. 1978. Estudios ecológicos en Euxesta stigmatias y Euxesta annonae (Diptera: Otitidae). Agric. Téc. (Chile) 38:89-94.

Frías, D.L. 1981. Diferencias de microhabitats entre Euxesta eluta y Euxesta annonae (Diptera: Otitidae). Agric. Téc. (Chile) 41:110-114.

Gallardo, F.E., V.A. Reche, I. Bertolaccini, B. Zárate, y C. Curis. 2017. A new genus and species of Eucoilinae (Hymenoptera, Cynipoidea, Figitidae) parasitoid of Euxesta eluta Loew (Diptera, Otitidae) attacked Bt sweet corn in Argentina. Journal of Hymenoptera Research 54:57-70. 
Huepe, S.G., H.C. Vargas, D.L. Frías, y D.G. Bobadilla. 1986. Estudio morfológico y ecológico de Euxesta eluta Loew y Euxesta mazorca Steyskal (Diptera: Otitidae) en cultivares de maíz en el Valle de Lluta, Arica. Rev. Chil. Entomol. 14:17-24.

INTA. 1991. Carta de suelos de la República Argentina. 25-26. 3160 p.

Kalsi, M., D.R. Seal, G.S. Nuessly, J.L. Capinera, and C.G. Martin. 2014. Distribution of arthropod predators and their responses to Euxesta spp. (Diptera: Ulidiidae) in the laboratory and in cornfields in South Florida. Florida Entomologist 97(3):911-920.

Köppen, W. 1948. Climatología: un estudio de los climas de la tierra. Trad. Pedro H.R. Pérez. Fondo de Cultura Económica, México.

MacRae, I., and J.S. Armstrong. 2000. High soil moisture effects on pupation of sugar beetroot maggot, Tetanops myopaejormis (Roder) (Diptera: Otitidae). J. Sugar Beet Res. 37(2):33-40.

Nuessly, G.S., and J.L. Capinera. 2006. Cornsilk fly. Gainsville, Florida. University of Florida Institute of Food and Agricultural Sciences. Disponible en http://creatures.ifas.ufl.edu/ field/cornsilk_fly.htm (Accessed 3 March 2016).

Nuessly, G.S., and J.L. Capinera. 2010. Euxesta stigmatias Loew (Insecta: Diptera: Ulidiidae). Featured creatures. Entomology and Nematology Dept., IFAS, Univ. Florida, USA. Available at http://entnemdept.ufl.edu/ creatures/ field/cornsilk_fly.htm (Accessed 3 May 2016).
Owens, D., G.S. Nuessly, and M. Gates. 2015. Pachycrepoideus vindemmiae (Hymenoptera: Pteromalidae) as a potential natural enemy of maize-infesting Ulidiidae. Florida Entomologist 98(1):276-279.

Seal, D.R., R.K. Jansson, and K. Bondari. 1996. Abundance and reproduction of Euxesta stigmatis (Diptera: Otitidae) on sweet corn in different environmental conditions. Florida Entomologist 79(3):413-422.

Souto, K.C.F.L., C.D. Pereira, and C. Lomônaco. 2011. Body size, symmetry and abundance of Euxesta stigmatias (Loew) and Euxesta sororcula (Wiedemann) (Diptera: Ulidiidae) in a natural reserve and in a guava orchard in Uberlândia, MG, Brazil. Neotropical Entomology 40(6):661-668.

TuTiempo.net. 2017. Disponible en http:// www.tutiempo.net/clima/Sauce_Viejo_ Aerodrome/12-2016/873710.htm (Consulta 2 marzo 2017).

Viana, P.A., I. Cruz, and J.M. Waquil. 2002. Controle de pragas no cultivo do milho verde. 217 p. En Pereira Filho, I.A. (ed.). O cultivo do milho verde. Embrapa, Brazil, D.F. 